\title{
The palynological record across the Cretaceous-Tertiary boundary in differing palaeogeographical settings from the southern Pyrenees, Spain
}

\author{
M. T. FERNÁNDEZ-MARRÓN ${ }^{1}$, N. LÓPEZ-MARTÍNEZ ${ }^{1}$, \\ J. F. FONOLLÁ-OCETE ${ }^{1} \&$ M. F. VALLE-HERNÁNDEZ ${ }^{2}$ \\ 'Dept./UEI Paleontología, Universidad Complutense/CSIC, Facultad C. Geológicas, 28040 \\ Madrid,Spain (e-mail: emarron@geo.ucm.es) \\ ${ }^{2}$ Area Paleontologia, Facultad Ciencias, Universidad de Salamanca, 37008 Salamanca, \\ Spain
}

\begin{abstract}
North American and Pacific spore-pollen records show a major extinction event at the Cretaceous-Tertiary (K-T) boundary, and abrupt changes are similarly found in many marine organisms world-wide. In contrast, records from the Old World reveal little evidence of terrestrial vegetational change across the boundary. In order to improve the characterization of changes across the $\mathrm{K}-\mathrm{T}$ boundary, palynological assemblages from two sections in the southern Pyrenees have been evaluated. The abundance and diversity of trilete fern spores are high in Maastrichtian samples and show a statistically significant decrease during the Danian. The 'fern spike' of low-diversity spores found elsewhere is not recorded in the Pyrenean region. Minor replacements of taxa across the $\mathrm{K}-\mathrm{T}$ boundary are also noted, as well as an increase in inaperturate gymnosperm pollen in the Danian. Comparing our two examined sections with one another reveals important differences in angiosperm pollen composition.
\end{abstract}

Jramatic floral changes have been documented across the Cretaceous-Tertiary $(\mathrm{K}-\mathrm{T})$ boundary in the North American and Pacific records. Here, a major extinction event in the plant record, and a sudden, brief increase in fern abundance (the 'fern spike'), have been correlated with an iridium anomaly related to an extraterrestrial impact at the boundary (Johnson et al. 2000; Vajda et al. 2001, and references therein). However, the palynological record in the Old World has not yet shown any appreciable changes during this critical period, which hinders the detection of the $\mathrm{K}-\mathrm{T}$ boundary. Until now, some of the best-documented continuous sections dated by biostratigraphy and magnetostratigraphy across the $\mathrm{K}-\mathrm{T}$ boundary in Europe and Africa have failed to show any significant palynological changes (Méon 1990, 1991; Médus et al. 1988, 1992; López-Martínez et al. 1999; Mayr et al. 1999). This lack of a clear palynological K-T boundary in the Old World contrasts with the abrupt change observed in the fossil record of many protists (coccoliths, planktonic foraminifera) and metazoans (molluscs, sharks and reptiles).

In the Pyrenean Basin, a thick succession of red beds characterizes the Tremp Formation, which dates from Late Cretaceous to Early Tertiary. Within this succession Ashraf \& Erben
(1986) recorded an impoverishment of plant species, which they interpreted as representing the palynological K-T boundary. However, biostratigraphic and magnetostratigraphic dating subsequently demonstrated an older age for this interval - at around the CampanianMaastrichtian transition (sensu Gradstein et al. 1995; López-Martínez et al. 1999; Ardèvol et al. 2000; López-Martínez et al. 2001). A decrease in plant diversity is recorded in other Old World regions (Stets et al. 1996; Markevitch et al. 2000), but this event can be correlated better with the Campanian-Maastrichtian transition than with the $\mathrm{K}-\mathrm{T}$ boundary. Therefore, no regional events in the Old World Late Cretaceous palynological succession have yet been demonstrably correlated with this boundary.

The apparently smooth transition across the $\mathrm{K}-\mathrm{T}$ boundary in the palynological record of the Old World may be due to incomplete sampling or to palaeoenvironmental factors. We have therefore studied the palynological record across the boundary in the south central Pyrenees (Spain) by comparing two sections about $50 \mathrm{~km}$ apart in differing palaeogeographical settings:

(1) The Fontllonga section (Lleida, Catalonia) representing upper estuarine deposits with a

From: BeAudoIn, A.B. \& HEAD, M.J. (eds) 2004. The Palynology and Micropalaeontology of Boundaries. Geological Society, London, Special Publications 
sedimentation rate between 10 and $100 \mathrm{~m}$ $\mathrm{Ma}^{-1}$ near the K-T boundary (AlvarezSierra et al. 1994; López-Martínez et al. 1998a; Mayr et al. 1999).

(2) The Campo section (Huesca, Aragón), a highly expanded stratigraphic section of marine platform deposits with a sedimentation rate up to $200 \mathrm{~m} \mathrm{Ma}^{-1}$ (López-Martínez et al. 1998b; Ardèvol et al. 2000; Fernández-Marrón et al. 2000).

Correlating two palynological successions across the $\mathrm{K}-\mathrm{T}$ boundary from the same region but representing different palaeogeographical settings should help to detect the palaeoenvironmental, climatic and evolutionary factors that affected the plant fossil record during this critical interval.

\section{Geological setting}

The south central Pyrenees (Spain) contain a rich geological record across the CretaceousTertiary transition, represented by marine and non-marine deposits from the Aren and Tremp Formations (Fig. 1). Middle Campanian to Jalaeocene deposits exceeding $2000 \mathrm{~m}$ in thickness are preserved in excellent outcrops. The Aren Formation consists of biocalcarenitic and hybrid sandstones from nearshore environments, intercalated with offshore marls and turbidite deposits basinwards (i.e. westwards); its age ranges from Mid-Campanian to Late Maastrichtian. The Tremp Formation consists of red beds and peritidal limestones deposited in coastal and continental settings. The middle part of the formation contains the $\mathrm{K}-\mathrm{T}$ boundary; its lower part intercalates with the Aren Formation (Ardèvol et al. 2000; López-Martínez et al. 2001).

The Fontllonga and Campo sections are situated in the South Pyrenean Central Unit, which is a complex allochthonous tectonic slab formed by a detached Mesozoic cover thrust over the foreland Ebro Basin. The South ?yrenean Central Unit is made up of several thrust sheets, which have noticeably shortened the original distance between sections. The Fontllonga and the Campo sections are separated by the Montsec thrust anticline (Fig. 1), whose shortening effect has been estimated at least about $17 \mathrm{~km}$ (Ardèvol et al. 2000).

The Fontllonga section $\left(41^{\circ} 58^{\prime} \mathrm{N}, 0^{\circ} 51^{\prime} \mathrm{E}\right)$, situated on the Ager syncline at Lleida, is located within the Sierras Marginales thrust sheet, which consists of Jurassic, Upper Cretaceous and Palaeogene limestones and sandstones overlying Upper Triassic gypsum. The Tremp
Formation here consists of about $700 \mathrm{~m}$ of Campanian to Palaeocene red beds, interpreted as transitional marine/non-marine sediments (paralic deposits) formed in peritidal and upper estuarine palaeoenvironments. Mixed marine and freshwater influence within this red bed succession is attested by tidal sedimentary structures (sigmoidal cross-stratification, mud drapes), remains of marine organisms (the cyanobacterium Girvanella, marine dinoflagellates, and the rays Igdabatis and Rhombodus) and marine bioclastic components within the sandstones (red algae, marine molluscs), remains of terrestrial and lacustrine organisms (dinosaur eggshells, continental ostracodes and molluscs) and isotopic composition (Álvarez-Sierra et al. 1994; López-Martínez et al. 1998a; Mayr et al. 1999).

The Campo section $\left(42^{\circ} 23^{\prime} \mathrm{N}\right.$ and $\left.0^{\circ} 24^{\prime} \mathrm{E}\right)$ is located in the Cotiella thrust sheet, formed by Upper Cretaceous and Palaeogene platform limestones, slope breccias, marls and turbidites. Campanian and Maastrichtian deposits here reach more than $2000 \mathrm{~m}$ in thickness, formed by turbidites and marls in the lower part, and deltaic sandstones and shelfal calcarenites in the upper part. The overlying red beds equivalent to the lower Tremp Formation consist of a $60-\mathrm{m}$ thick interval comprising red mudstones and sandstones with minor intercalations of black shales and dolostones (Eichenseer 1988; Robador et al. 1990). This section is situated in a basinward position relative to Fontllonga. The marine origin of the Campo red beds is attested by the presence of non-reworked dinoflagellates, micro- and macroforaminifera (Laffiteina bibensis), authochthonous rudists and a drifted ammonite shell (Pachydiscus gollevillensis).

\section{The Cretaceous-Tertiary boundary}

The Cretaceous-Tertiary boundary has been located within the middle of the Tremp Formation in the south central Pyrenees, using biostratigraphy (foraminifera, charophytes, rudists, ammonites, vertebrates), magnetostratigraphy and chemostratigraphy. In the Fontllonga section, the $\mathrm{K}-\mathrm{T}$ boundary occurs within a 1- to $3-\mathrm{m}$ thick lutite interval near the top of a thick sandstone unit correlated with Chron C29r (Galbrun et al. 1993). Dinosaur remains are common below this interval but disappear just above it, where a $\delta^{13} \mathrm{C}$ isotopic anomaly indicates a marked change in organic productivity. Vertebrate remains allow this geochemical anomaly to be placed in the earliest Palaeocene (López-Martínez et al. 1998a, 1999). 


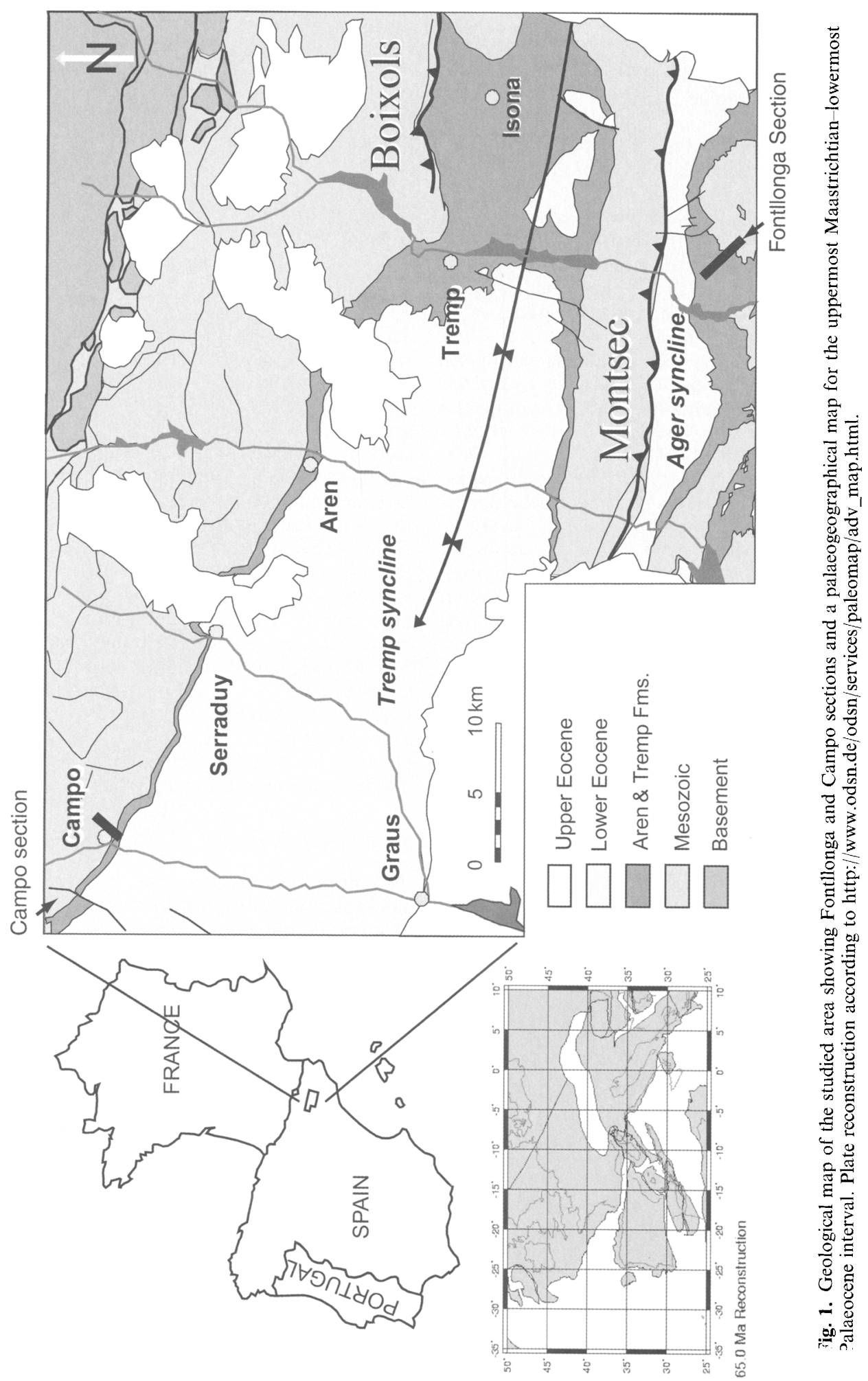


In the Campo section, stable isotopic analyses have not yet revealed a $\delta^{13} \mathrm{C}$ isotopic anomaly related to the $\mathrm{K}-\mathrm{T}$ boundary. Preliminary magnetostratigraphic analyses have shown reversed polarity in the uppermost $30 \mathrm{~m}$ of the Aren Sandstone and in the $60-\mathrm{m}$ thick lower Tremp Formation (Galbrun et al. in press) that is compatible with Chron $\mathrm{C} 29 \mathrm{r}$ containing this boundary. Biostratigraphic interpretation relies on the presence of the benthic foraminiferid Laffiteina bibensis in the middle part of the red beds. This species has been interpreted as being earliest Palaeocene in age, by Serra-Kiel et al. (1998), who used it as a marker for their lowermost Tertiary SBZ-1 biozone. However, in the Campo section this species is associated with rudists and ammonites, which confirms its Zretaceous age as deduced in other regions (Eichenseer 1988; Loeblich \& Tappan 1988; López-Martínez et al. 1998b). Palaeocene charophyte taxa are reported just above the uppermost rudist- and ammonite-bearing level (Y. Tambareau, pers. comm.). The foraminiferid Laffiteina bibensis is observed until approximately $55 \mathrm{~m}$ above the base of the Tremp Formation (Fig. 2). Therefore, the $\mathrm{K}-\mathrm{T}$ boundary in the Campo section can be placed above the highest occurrence of rudists, ammonites and dinosaurs and below the massive carbonate Unit 3 of Danian age, correlated to the middle part of the Tremp Formation and to the Salarons Formation (Eichenseer 1988; Robador et al. 1990; Fig. 2). Lithostratigraphic correlation indicates that the $\mathrm{K}-\mathrm{T}$ boundary can probably be placed within the lower $10 \mathrm{~m}$ of this 16-m thick interval, which corresponds with a reversed magnetic polarity interval (Galbrun et $a l$. in press; O. Oms, pers. comm.).

In continental sections from the Old World, no iridium anomaly has yet been associated with a $\mathrm{K}-\mathrm{T}$ boundary level as determined by biostratigraphic methods. The Fontllonga and Jampo sections are among the best-calibrated Jld World continental sections for this critical period. Although hiatuses across the $\mathrm{K}-\mathrm{T}$ boundary interval cannot be excluded, they are not likely in either section: the critical interval in both sections lies within a thick reversed magnetic interval correlated with Chron C29r. $\mathrm{n}$ the Fontllonga section, the stratigraphic interval correlated with Chron $\mathrm{C} 29 \mathrm{r}$ is $35.8 \mathrm{~m}$ thick, whereas in the Campo section it exceeds $38 \mathrm{~m}$. The $\mathrm{K}-\mathrm{T}$ boundary interval in the Fontllonga section is situated within a detrital unit whose sedimentation rate is estimated at about $50 \mathrm{~m} / \mathrm{Ma}^{-1}$. The uppermost part of the Chron C29r interval, which is of Tertiary age, corresponds to a limestone unit with palaeosols, indicating a strong drop in sedimentation rate. For this reason, the $\mathrm{K}-\mathrm{T}$ boundary lies near the top of the Chron $\mathrm{C} 29 \mathrm{r}$ interval in this section (Fig. 2).

The Campo section does not yet have a clearly delimited Chron C29r interval. A hiatus is expected to be present in the Danian part of the section (above CP-13 sample, Fig. 2) because the normal polarity chrons $\mathrm{C} 29 \mathrm{n}$ and $\mathrm{C} 28 \mathrm{n}$ are lacking.

\section{Palynology}

This study analyses data statistically from nine samples of the Fontllonga section (two samples from López-Martínez et al., 1999; six samples from Mayr et al., 1999; and the newly analysed sample \#31) and six samples of the Campo section (all newly analysed). Indices employed are the abundance (number of specimens) and diversity (number of species) of spores relative to the total spore-pollen assemblage, excluding fungi. The indices are treated as percentages. Spores include bryophytes, lycopods and ferns; whereas pollen includes gymnosperms and angiosperms. The total number of spores and pollen counted per sample ranges between 29 and 632 specimens (average of 185) for our samples and those of López-Martínez et al. (1999), and between 90 and 270 specimens (average of 162) for those of Mayr et al. (1999). The data for each sample are given in Tables 1 to 3 and in Figure 3.

\section{Fontllonga section}

The Fontllonga section has been repeatedly sampled for palynology in order to detect changes in the floral composition across the K-T boundary (Médus et al. 1988, 1992; LópezMartinez et al. 1999; Mayr et al. 1999). The Fontllonga palynological record includes samples from the boundary interval studied by Médus et al. (1988), two samples embracing the boundary studied by López-Martínez et al. (1999, samples F\#32 and F\#36) and six samples studied by Mayr et al. (1999), three of them from the Maastrichtian (CH-21, $\mathrm{CH}-25$ and $\mathrm{CH}-26)$ and three from the Lower Danian $(\mathrm{CH}-16, \mathrm{CH}-$ 27 and $\mathrm{CH}-20$ ). Mayr et al. (1999) included another Danian sample from the neighbouring Figuerola section. These previous studies show only small, fluctuating changes in the palynological succession across the $\mathrm{K}-\mathrm{T}$ boundary.

In our study we included another palynological assemblage dated as Late Maastrichtian (sample F\#31); additional intermediate samples were prepared but did not contain palyno- 


\section{Fontllonga}

\section{Campo}

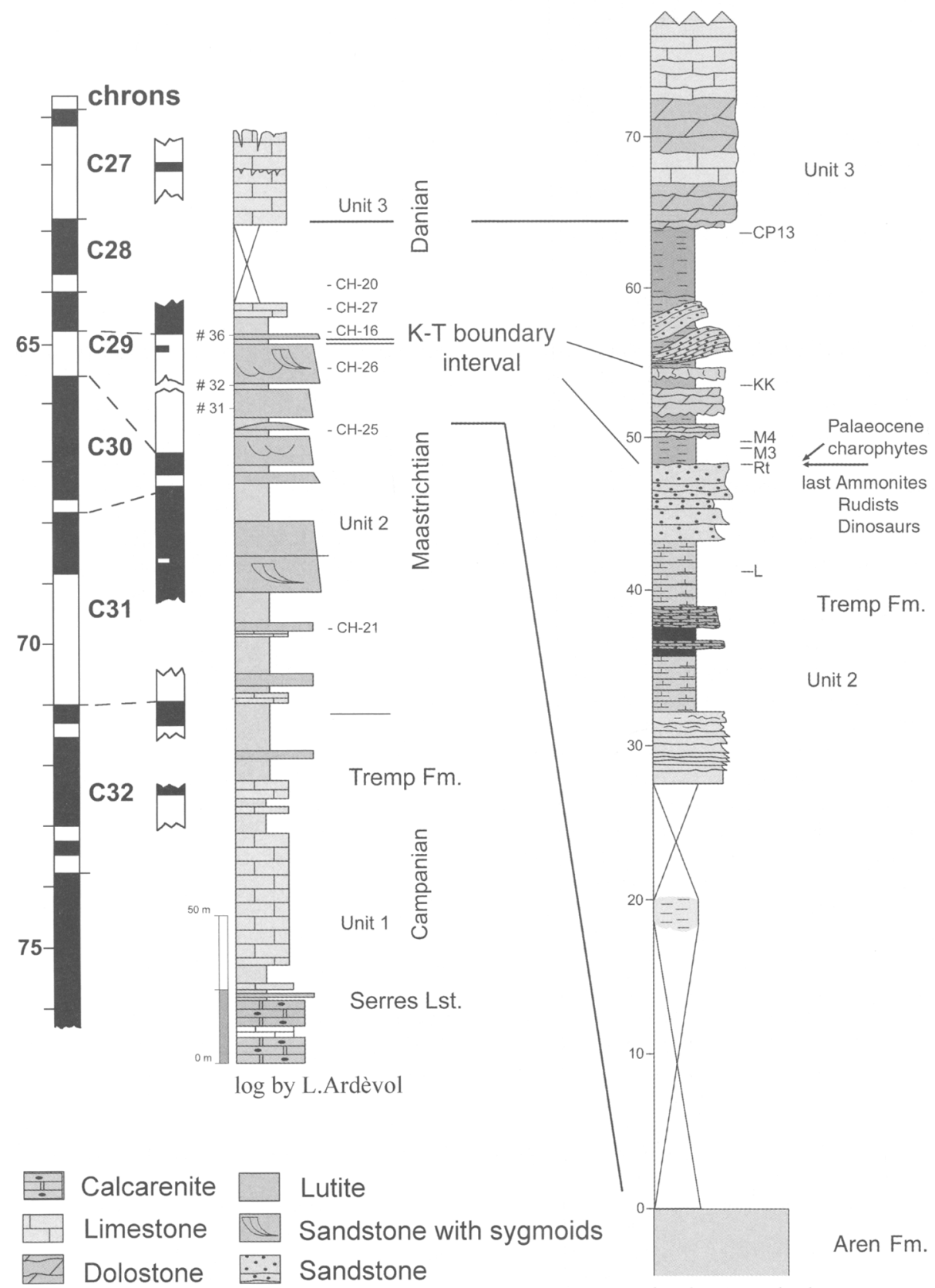

$\log$ by A. Robador

iig. 2. The position of palynological samples evaluated in the present study. Left, Fontllonga stratigraphic 'ection showing palaeomagnetic polarity and proposed correlation (Galbrun et al. 1993; López-Martínez et al. 1998a; and Mayr et al. 1999). Sample \#31 is from the present study, samples \#32 and \#36 are from López.Tartínez et al. (1999), and samples CH-16 to CH-27 are from Mayr et al. (1999). Right, Campo stratigraphic ection corresponding mostly with a reversed polarity chron assumed to be C29r. Lines of correlation to the Fontllonga section are based on sequence stratigraphy and biostratigraphy (Robador et al. 1990; Ardevol et al. $3000)$ 
Table 1. Comparison of spore frequency (species diversity and relative abundance) in palynomorph assemblages below and above the $K-T$ boundary in the Fontllonga section.

\begin{tabular}{lcccccccc}
\hline Fontllonga section & \multicolumn{3}{c}{ Diversity (\%) } & & \multicolumn{3}{c}{ Abundance (\%) } & \multirow{2}{*}{ No. of sample. } \\
\cline { 2 - 3 } & Max. & Mean & Min. & & Max. & Mean & Min. & \\
\hline Uppermost Maastrichtian & 66.7 & 50.5 & 40.0 & & 78.7 & 54.8 & 30.1 & 6 \\
Lowermost Danian & 50.0 & 43.1 & 36.4 & & 48.0 & 37.0 & 28.5 & 4 \\
$t$-test probability & & $16.4 \%(-)$ & & & $7.3 \%(-)$ & & \\
\hline
\end{tabular}

Data from López-Martínez et al. (1999), Mayr et al. (1999) and new data from this work (see Table 3). $(-)$ not statistically significant.

morphs. The positions of all samples statistically analysed in this paper for the Fontllonga section are shown in Figure 2.

Spores are the main component of the three palynomorph assemblages, and are generally large trilete types: psilate Leiotriletes spp. and Cyathidites spp., ornamented and thick-walled Lycopodiumsporites sp., Matthesisporites plurituberosus Döring, Polypodiaceoisporites spp. and Echinatisporis spp., as well as cingulate Patellasporites sp. and taeniate Cicatricosisporites $\mathrm{sp}$. spores. The flora was thus dominated by lycopods and ferns, mainly from the Schizaceae, Gleichenidaceae, Cyatheaceae and Polypodiaceae families. Thick-walled spores reach $90-94 \%$ of the spore assemblage, indicating the strong influence of locally developed fern forests.

The spores Biretisporites potoniaei Delcourt \& Sprumont, Matthesisporites plurituberosus Döring and Trilites tuberculiformis (Cookson) Dettman, proposed as Cretaceous markers by Asraf \& Erben (1986), appear in our Cretaceous assemblage F\#31 from Fontllonga. However, Mayr et al. (1999) also reported these species from Danian samples in the Fontllonga area.

The predominance of spore diversity and abundance over pollen is particularly high in the Cretaceous samples, although the difference is not large (Fig. 3). Mayr et al. (1999) also reported an increase in trilete spore abundance and diversity within the uppermost Maastrichtian in the Fontllonga section, and interpreted this dominance as indicative of environmental change across the $\mathrm{K}-\mathrm{T}$ boundary. When all samples are considered, the palynomorph assemblages below this boundary actually show an overall dominance in spores samples above the boundary, but the difference is not statistically significant (a 7\% probability of a null hypothesis remains; see Table 1). Both spore diversity and abundance decrease across the $\mathrm{K}-\mathrm{T}$ boundary, but the difference in the Fontllonga samples is too low and the overlap too high to be significant as a biostratigraphic boundary criterion.

In the Fontllonga section, those samples containing the highest spore abundance (F\#32 and $\mathrm{CH}-25,71-78 \%$ ) are very close to the $\mathrm{K}-\mathrm{T}$ boundary but are not the closest. Older Campanian and Maastrichtian samples from other Pyrenean areas show even higher spore ratios in the palynomorph assemblages, reaching as much as $85.3 \%$ diversity and $88.4 \%$ abundance (De Porta et al. 1985; Ashraf \& Erben 1986;

Table 2. Comparison of spore frequency (species diversity and relative abundance) in palynomorph assemblages across the $K-T$ boundary for the combined Fontlonga and Campo sections.

\begin{tabular}{|c|c|c|c|c|c|c|c|}
\hline \multirow[t]{2}{*}{ Tontllonga and Campo sections } & \multicolumn{3}{|c|}{ Diversity (\%) } & \multicolumn{3}{|c|}{ Abundance $(\%)$} & \multirow[t]{2}{*}{ No. of samples } \\
\hline & Max. & Mean & Min. & Max. & Mean & Min. & \\
\hline $\begin{array}{l}\text { Uppermost Maastrichtian and } \\
\mathrm{K}-\mathrm{T} \text { boundary interval }\end{array}$ & 74.6 & 58.6 & 40.0 & 80.8 & 61.6 & 30.1 & 11 \\
\hline $\begin{array}{l}\text { Lowermost Danian } \\
t \text {-test probability }\end{array}$ & 50.0 & $\begin{array}{c}44.5 \\
3.5 \% *\end{array}$ & 36.4 & 48.1 & $\begin{array}{l}37.3 \\
0.07 \%\end{array}$ & 28.5 & 5 \\
\hline
\end{tabular}

Data from López-Martínez et al. (1999), Mayr et al. (1999), Fernández-Marrón et al. (2000) and new data from this work (see Table 3).

${ }^{*}$ Statistically significant.

†Highly sionificant. 


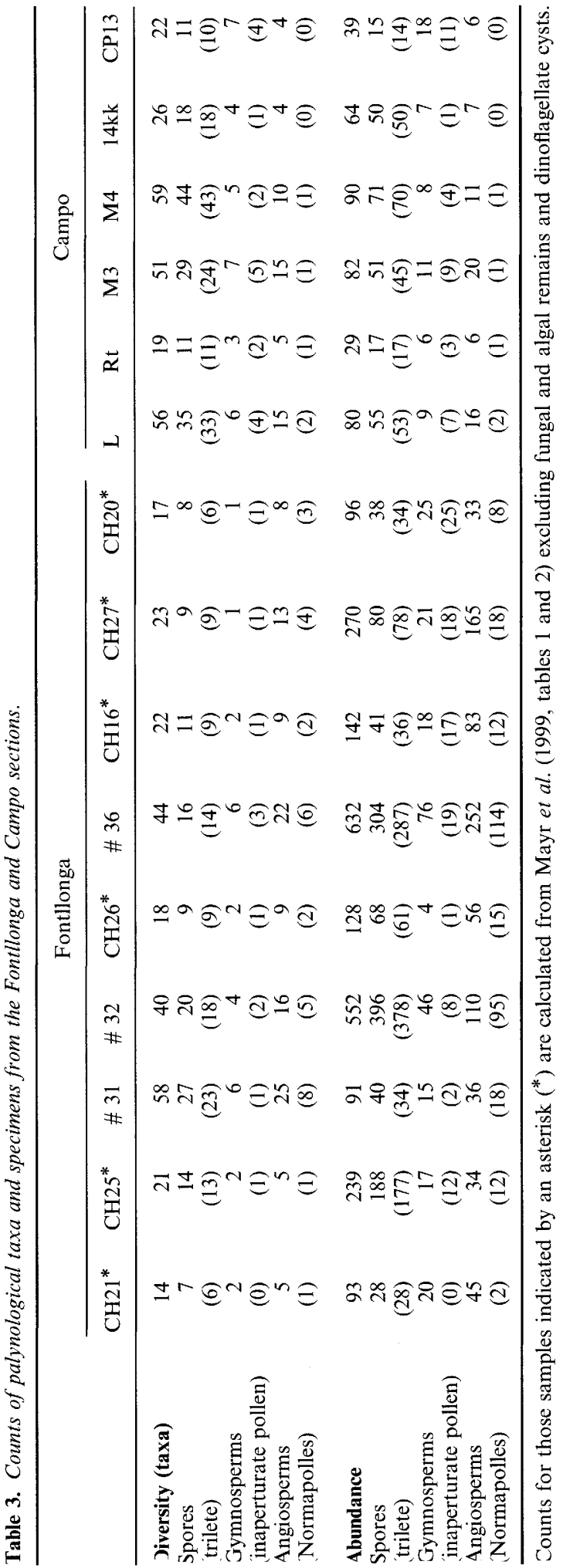



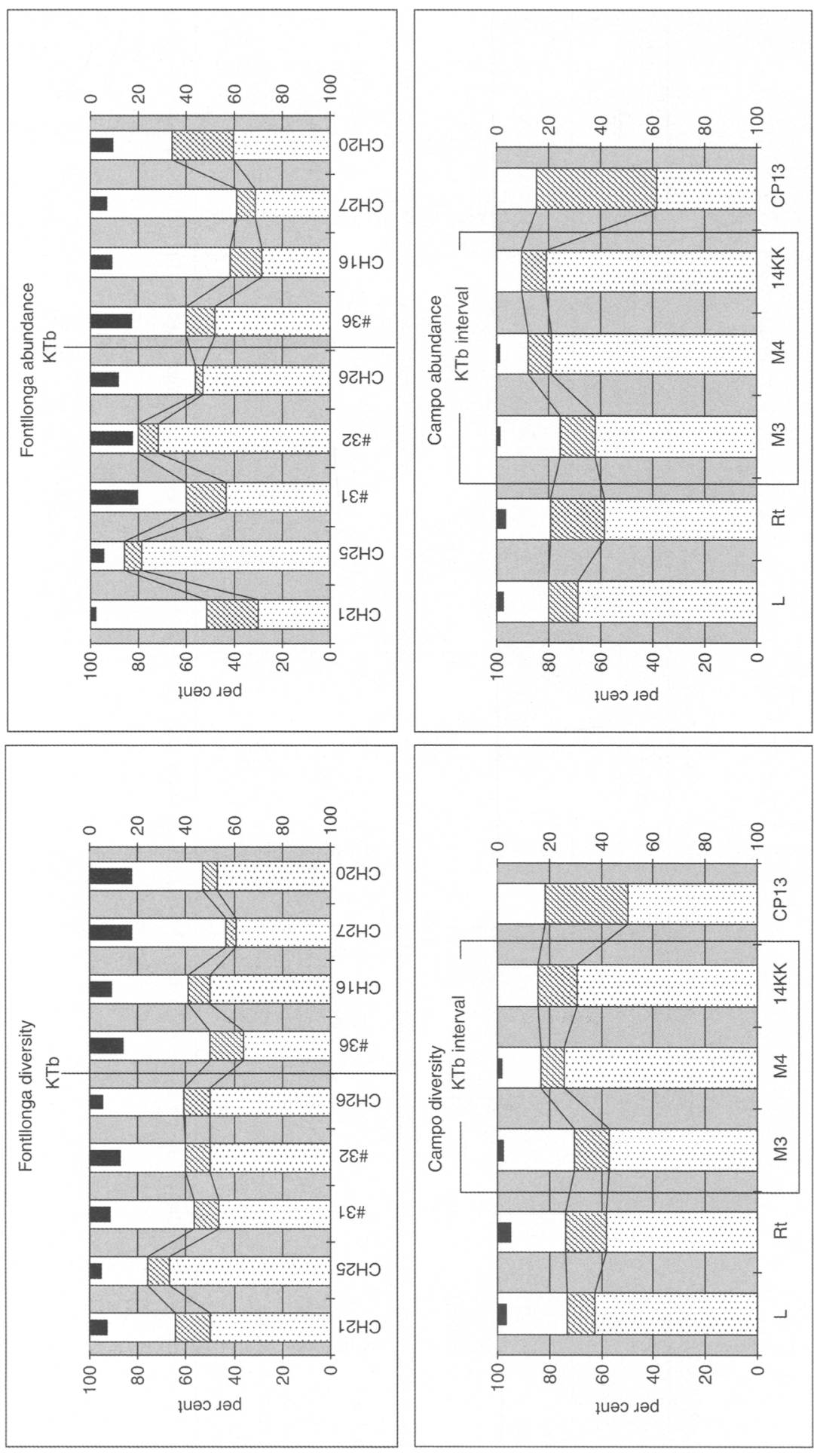
Médus et al. 1988). Therefore, during latest Cretaceous times, the Pyrenean region was already dominated by ferns, which increases the difficulty in detecting a fern spike similar to those reported for North America and New Zealand just above the $\mathrm{K}-\mathrm{T}$ boundary (Fleming \& Nichols 1990; Vajda et al. 2001).

Gymnosperms are a minor component of the palynomorph assemblages in the Fontllonga section, reaching about $10 \%$ of the total diversity and abundance. Cupressaceae-Taxodiaceae and Cycadaceae are the main components, the Pinaceae being extremely rare both in uppermost Cretaceous and Palaeocene samples. Samples studied by Mayr et al. (1999) around the K$\mathrm{T}$ boundary in the Fontllonga section also show a very similar gymnosperm ratio and composition. A proposed increase in Pinaceae abundance after the boundary as a biostratigraphic criterion in the Fontllonga section (Médus et al. 1992) can therefore be excluded. The frequency of bisaccate pollen is often related to taphonomic factors, and in marine samples is extremely sensitive to the distance of the sample location from shore.

The pollen composition in the Fontllonga section shows a major angiosperm component, reaching more than $40 \%$ of the total sporepollen assemblage. A diverse angiosperm flora includes: Tricolpopollenites sp., Polycolpites sp., Rugulitriporites sp., Subtriporopollenites sp., Triporopollenites spp., Polyporopollenites sp., Triatriopollenites sp., etc. The Normapolles group (Trudopollis sp., Vacuopollis sp., Semioculopollis sp., Nudopollis sp.) is an important component, comprising about $12 \%$ of the total assemblage diversity and $18 \%$ of the abundance, although Mayr et al. (1999) reported a lower Normapolles abundance and diversity (lower than $10 \%$ ). The Normapolles Pseudoromeinipollenites cf. paleocenicus occurs only in Tertiary samples from Fontllonga, according to our results and those of Mayr et al. (1999). This species may be characteristic of the European Tertiary and different from Cretaceous forms attributed to the same genus by Médus (1986) and Médus et al. (1988).

\section{Sampo section}

In order to obtain the highest resolution record possible across the $\mathrm{K}-\mathrm{T}$ boundary, the more expanded Campo section has been chosen to explore the palynological pattern of plant change. Chron $\mathrm{C} 29 \mathrm{r}$ containing the boundary may here span more than $90 \mathrm{~m}$ in thickness, compared with around $50 \mathrm{~m}$ in the Fontllonga section. Moreover, the grey-black shale and clay-dominated deposits of the $\mathrm{K}-\mathrm{T}$ transition in the Campo section are more favourable to continuous deposition and palynomorph preservation than in the Fontllonga section, where an amalgamation of channel sandstones correlated to Chron C29r presumably contain stratigraphic hiatuses.

The red-bed interval in the Campo section has yielded six significant palynological assemblages among the numerous studied samples. Two (samples $\mathrm{L}$ and $\mathrm{Rt}$ ) correspond with the uppermost Maastrichtian levels containing Laffiteina bibensis, rudists and ammonites; three sample: above them (M3, M4 and KK) correspond to a 10-m thick interval where the $\mathrm{K}-\mathrm{T}$ boundary can probably be situated; and the highest analysed sample (CP-13) is considered Tertiary in age because of its close proximity to the Danian limestone unit (Fig. 2).

The total diversity in the Campo samples is similar to that in Fontllonga (an average of about $40 \mathrm{v} .47$ taxa per sample), in spite of fewer specimens counted (66 v. 425 average specimens per sample respectively). However, the variance between samples is much more important in the Campo section (standard deviation 18.4 v. 9.4). The dominance of spores over pollen in the Campo samples, both in diversity $(50 \%$ spore taxa on average) and abundance (65\% spore specimens on average), is even stronger than in the Fontllonga section (44\% and 54\% respectively) (Fig. 3). We note the lack of cingulate and teniate spores in Campo, which are present in Fontllonga.

The trilete spore species Biretisporites potoniei Delcourt \& Sprumont, Cyathidites minor Couper, Lycopodiumsporites austroclavatidites (Cookson) Potonié, Matthesisporites plurituberosus Döring and Polypodiaceoisporites potoniei (Potonié \& Gelletich) Kedves, which are restricted to the Maastrichtian according to Asraf \& Erben (1986), occur in the lowermost five spore assemblages analysed from the Campo section and are absent from the Danian sample CP-13. However, three of these taxa are reported by Mayr et al. (1999) in the Danian samples from Fontllonga (see above). More sampling is necessary to confirm that at least two of these forms were extinct after the $\mathrm{K}-\mathrm{T}$ boundary.

The previously noted increased spore-pollen ratio below the $\mathrm{K}-\mathrm{T}$ boundary at Fontllonga is also seen in assemblages from the $\mathrm{K}-\mathrm{T}$ boundary interval in the Campo section, which may be chronologically closer to the boundary than those from the Fontllonga section (FernándezMarrón et al. 2000). The Upper Maastrichtian L and $\mathrm{Rt}$ assemblages reach around $60-70 \%$ in spore diversity and abundance; the spore ratio 
noticeably rises in the M4 and KK samples (around $70-75 \%$ diversity and $80 \%$ abundance), and decreases to $40-50 \%$ in the Danian CP-13 assemblage.

Gymnosperms are hardly more abundant in the Campo assemblages than in those of Fontllonga. We record three to seven taxa per sample with 9-20\% average abundance. Only the Janian sample CP-13 shows a massive presence of gymnosperms, mainly Inaperturopollenites $\mathrm{sp}$. (up to $32 \%$ diversity and $46 \%$ abundance, Fig. 3 ). This pollen form is present in all samples as well as Araucariacites sp. and pollen related to the Cycadophyta. Bisaccate pollen are rare. In all of the Campo samples, angiosperms are poor, both in diversity (average 22\%) and abundance $(17 \%)$, in relation to the total spore-pollen assemblage (Fig. 3). The pollen genus Subtriporopollenites which is represented by several species, together with Triatriopollenites $\mathrm{sp}$. and Polycolpites sp., are the only significant components, whereas the Normapolles presence is insignificant (average 2\% diversity and less than $1 \%$ abundance). Hence, the angiosperm pollen frequency from the Campo succession differs strongly from that of Fontllonga, this difference being statistically highly significant in both diversity and abundance (null hypothesis probability $p=0.0002$ and $p=0.002$ respectively, according to the t-test).

Both angiosperm and Normapolles frequencies decrease upwards in the Campo palynological succession, although the numbers of specimens counted in the youngest samples are not yet large enough to be conclusive. The extraordinarily low percentage of Normapolles in the Campo samples (less than $1 \%$ of about 400 counted specimens) seems related to a very low representation of angiosperms, and not to a replacement by modern-type angiosperms which is a long-term trend across the CretaceousTertiary transition (López-Martínez et al. 1999). However, the Normapolles decline needs to be fully validated before being considered a reliable signal (see below).

\section{Comparison between sections}

When palynological samples from both the Fontllonga and Campo sections are considered together, the observed changes in spore-pollen ratio across the $\mathrm{K}-\mathrm{T}$ boundary show a consistent pattern. The difference in spore-pollen ratio becomes reinforced and statistically significant or highly significant (Table 2). On average, the spore-pollen ratio across the $\mathrm{K}-\mathrm{T}$ boundary falls from $59 \%$ diversity and $62 \%$ abundance, to $45 \%$ diversity and $37 \%$ abundance. Sample CP-
13 from Campo closely fits the ratio of Tertiary samples from the well-dated Fontllonga section, which supports its Danian age. The three samples from the Campo $\mathrm{K}-\mathrm{T}$ boundary interval are similar to those from the Cretaceous, although the boundary itself cannot yet be confidently placed in relation to them.

The spore occurrence pattern in the Campo section shows good correlation between diversity and abundance peaks (correlation coefficient $r=0.93$ ), indeed a much better correlation than at Fontllonga $(r=0.58)$ and also better than at other Pyrenean localities (La Posa and Coll de Nargó, $r=0.87$ ) (calculated from data in De Porta et al. 1985 and Ashraf \& Erben 1986). In contrast, the North American fern spike shows a high spore abundance with low diversity (Tschudy et al. 1984). The two New Zealand sections which document the fern spike differ, but both show a relatively high spore diversity, that includes both ground and tree ferns, for a duration of 30000 years (Vajda et al. 2001).

The unusual composition of gymnosperms from the Campo Tertiary sample shows some similarities with a Danian sample from the Figuerola section, near Fontllonga, in having an unusually high abundance of inaperturate pollen (Mayr et al. 1999). The New Zealand record also documents a gymnosperm-rich period during the Early Danian, lasting more than $1 \mathrm{Ma}$ after the fern spike and revealed by dominance of the conifer pollen Phyllocladidites (Vajda et al. 2001).

In contrast to the relatively rich and diverse angiosperms characterizing the Fontllonga assemblages, with Normapolles pollen comprising about half of the specimens, the low representation of Normapolles and other angiosperm pollen close to the $\mathrm{K}-\mathrm{T}$ boundary in the Campo section could be considered a palaeoenvironmental signal, indicating a regressive step in the vegetation successional sequence. The frequency of angiosperms is usually a rather consistent indicator in palynological composition. However, the Normapolles frequency in other Pyrenean palynological studies seems to be highly unstable when comparing data from different authors for the same localities. For example, our Normapolles frequences in the Fontllonga samples (17-19\% of a total of 1700 spores and pollen) are significantly higher than those for the same part of the section studied by Mayr et al. (1999) (5-11\% of up to 1455 spore. and pollen), in spite of good general agreement between both palynological studies. Also in $\mathrm{La}$ Posa grey marl samples (latest Campanian, lower Tremp Formation, Isona, Lleida), the Normapolles reach around $20 \%$ of specie: 
diversity according to De Porta et al. (1985), but only $1.4 \%$ according to Ashraf \& Erben (1986). These differences cannot be explained by random sampling effects or palaeoenvironmental factors, since the samples came from the same parts of the same section. The possibility that preparation techniques may affect the Normapolles frequency is another factor that needs to be studied. Meanwhile, we do not consider the Normapolles frequency to be a reliable signal in our analysis.

\section{Conclusions}

Palynological changes across the $\mathrm{K}-\mathrm{T}$ boundary in the south central Pyrenees have been portrayed in previous studies as following a smooth transition, with minor vegetational fluctuations linked to local palaeoenvironmental factors. We have re-evaluated a previously published palynological succession from the best time-constrained section, at Fontllonga, and have analysed an additional sample. New palynological data have also been collected from the highly expanded Campo section, situated in a more paralic environment and a palaeogeographical position more distal relative to the shoreline.

Our results lead to a better characterization of the palynological $\mathrm{K}-\mathrm{T}$ boundary. The most noticeable pattern in plant changes across this boundary in the Pyrenean realm is the increase in trilete spores during the latest Maastrichtian and $\mathrm{K}-\mathrm{T}$ boundary interval assemblages, and its decrease in the Danian assemblages. In our study, this pattern previously observed in the Fontllonga sections and in some localities in the south of France (Médus et al. 1988; LópezMartínez et al. 1999; Mayr et al. 1999; Fernández-Marrón et al. 2000) has been reinforced by showing that this difference is statistically highly significant, and by verifying the same pattern in the highly expanded Campo section. In the Jyrenees, a long interval, from uppermost Maastrichtian to the $\mathrm{K}-\mathrm{T}$ boundary interval, is characterised by taxonomically diverse as well as abundant trilete spores. This contrasts with the short-duration fern-spike at the K-T boundary in North America and New Zealand, where an abrupt increase in ferns represents a lowdiversity assemblage comprising the monolete form genus Laevigatosporites or the trilete form genus Cyathidites, respectively (Sweet et al. 1999; Vajda et al. 2001). It is therefore likely that the fern increase in our study is driven by different causal mechanisms from those of the fern spike in North America and New Zealand.
There are no noticeable extinctions across the $\mathrm{K}-\mathrm{T}$ boundary in the studied sections. Several biostratigraphic criteria previously proposed for delimiting the boundary need to be modified or rejected. The spore species Cyathidites minor Couper, Lycopodiumsporites austroclavatidites (Cookson) Potonié, and Polypodiaceoisporites potoniei (Potonié \& Gelletich) Kedves are recorded below and above the $\mathrm{K}-\mathrm{T}$ boundary, whereas Biretisporites potoniei Delcourt \& Sprumont, Matthesisporites plurituberosus Döring and Trilites tuberculiformis (Cookson) Dettman, which are only found in our Cretaceous assemblages, have nevertheless been reported from Danian samples by Mayr et al. (1999). All these species were proposed as Cretaceous markers by Asraf \& Erben (1986). An increase in bisaccate pollen after the K-T boundary is not observed and its fluctuations are not recommended as biostratigraphic criterion (Médus et al. 1992). The decrease in Normapolles abundance around the boundary (López-Martínez et al. 1999) is also a flawed criterion, since its fluctuations are based on unstable observations. Pseudoromeinipollenites cf. paleocenicus, if distinguishable from its Cretaceous relatives, would be a biostratigraphically significant newcomer after the $\mathrm{K}-\mathrm{T}$ boundary.

The increase in frequency of spores across the $\mathrm{K}-\mathrm{T}$ boundary is better marked in the Campo section, where two fern-rich samples from the $\mathrm{K}-\mathrm{T}$ boundary interval show extremely low proportions of angiosperm pollen. Following this increase in spores, two Tertiary samples from both sections show an unusual abundance in inaperturate gymnosperm pollen. This pattern in the palynological succession across the $\mathrm{K}-\mathrm{T}$ boundary is similar to that from other regions where a fern spike has been documented. This correlation would imply that the youngest sporerich samples from Campo could already correspond with the earliest Tertiary. This hypothesis can be tested by geochemical analyses across this palynologically constrained K-T boundary interval.

Funds were provided by projects PB98-0813 and BTE2002-01430 of the Spanish Ministerio de Educación and Ministerio de Ciencia \& Tecnología. We acknowledge the help of project members from Barcelona (UAB), Bilbao (UPV), Madrid (UCM), Rome (La Sapienzia) and Salamanca Universities, the Spanish Geological Survey (IGME), Institut d'Estudis Ilerdençs (IEI), Geoplay (Tremp, Lleida) and the villagers of Pallars Jussà (Catalonia) and Ribagorza (Aragón). We are also grateful to D. J. Nichols (US Geological Survey, Denver) and A. Sweet (Geological Survey of Canada, Calgary) for their helpful reviews of the manuscript, and especiallv to M. J. Head (Denart- 
ment of Geography, University of Cambridge) for his very careful editorial work.

\section{References}

Alvarez-Sierra, M. A., Arribas, M. E. ET $A L$. 1994. El límite Cretácico-Terciario en la sección de Fontllonga (Cuenca de Ager, provincia de Lérida). II Congreso GET Jaca, Comunicaciones, pp. 23 26.

ArdeVol, L., Klimowitz, J., MalaGón, J. \& NagtegaAl, P. J. C. 2000. Depositional sequence response to foreland deformation in the Upper Cretaceous of Southern Pyrenees, Spain. Bulletin of the American Association of Petroleum Geologists, 84, 566-587.

Ashraf, A. R. \& ERbEN, H. K. 1986. Palynologische Untersuchungen an der Kreide/Tertiar-Grenze west-mediterraner Regionen. Palaeontographica $B, 200,111-163$.

De Porta, J., Kedves, M., Solé De Porta, N. \& CIVIS, J. 1985. Palinología del Maastrichtiense del barranco de la Posa (Lérida, España). Problemática regional. Revista d'Investigacions Geologiques, 40, 5-28.

EICHENSEER, H. 1988. Facies geology of late Maastrichtian to early Eocene coastal to shallow marine sediments, Tremp Graus basin, NE Spain. Ph.D. Thesis, University of Tübingen, 237 pp.

Fernández Marrón, M. T., Fonollá Ocete, J. F., VAlle HernÁNDEZ, M. F., Robador, A. \& LÓPEZ MARTINEZ, N. 2000. Asociaciones esporopolínicas del Transito Cretácico-Terciario en la Sección de Campo, Cuenca de Tremp-Graus (Huesca). In: XIII Simposio de la Asociación de Palinólogos en Lengua Española, Cartagena, Libro de Resúmenes, pp. 195-196.

Fleming, R. F. \& Nichols, D. J. 1990. Fern-spore abundance anomaly at the Cretaceous-Tertiary boundary: a regional bioevent in western North America. In: KaUfFMAN, E. G. \& WALliser, O. H. (eds) Extinction Events in Earth History, Springer-Verlag, Berlin, Heidelberg, pp. 347349.

Galbrun, B., Feist, M., Colombo, F., Rocchia, R. \& TAMBAREAU, Y. 1993. Magnetostratigraphy and biostratigraphy of Cretaceous-Tertiary continental deposits, Ager basin, province of Lerida, Spain. Palaeogeography, Palaeoclimatology, Palaeoecology, 102, 41-52.

Galbrun, B., Ozawa, S., SAmso, J. M., HottinGer, Feist, M., Robin, E., RoCChiA, R. \& TAmbareau, L. (in press). About the age of Laffiteina bibensis Marie in the Garumnian facies of the Campo section (central South Pyrenean zone): Biostratigraphical, magnetostratigraphical studies and iridium anomaly prospects. Dela Opera, Ljubljana.

Gradstein, F. M., Agterberg, F. P., Ogg, J. G., Hardenbol, J., VAN Veen, P., ThierRy, J. HuANG, Z. 1995. A Triassic, Jurassic and Cretaceous time scale. In: BERGGREN, W. A., Kfnt, D. V., AunRY, M.P. \& HARDFnboi, J. (eds) Geochronology, Time Scales and Global Stratigraphic Correlation. SEPM (Society for Sedimentary Geology), Special Publication, 54, 95-126.

JOHNSON, K., NICHOLS, D., LABANDEIRA, C. \& PEARSON, D. 2000. Devastation of terrestrial ecosystems at the K-T boundary in North America: the first calibrated record of plant and animal response to the Chicxulub impact, In: Catastrophic Events and Mass Extinctions: Impacts and Beyond, Catastrophic Events Conference, Vienna, Austria, 2000, pp. 85-86.

LOEBLICH, A. \& TAPPAN, H. 1988. Foraminiferal Genera and their Classification. Van Nostrand Reinhold. New York.

López-Martinez, N., Ardevol, L., Arribas, M. E., Civis, J. \& Gonzalez Delgado, J. A. 1998a. The geological record in non-marine environments around the K/T boundary (Tremp Formation, Spain). Bulletin Société Geologique de France, 169(1), 11-20.

López-Martínez, N., CANudo, I. ET AL. 2001. New dinosaur sites correlated with Upper Maastrichtian pelagic deposits in the Spanish Pyrenees: implications for the dinosaur extinction pattern in Europe. Cretaceous Research, 22, 41-61.

López-Martinez, N., Civis, J. ET $A L .1998 b$. El límite Cretácico-Terciario en la sección de Campo (Cuenca de Tremp-Graus, Pirineos Sur-Centrales). Sedimentología, micropaleontología e isótopos estables de C y O. In: XIV Jornadas de Paleontología, Tenerife, Libro de Resúmenes, pp. 105-107.

López-MArtínez, N., Fernández MARrón, T. \& VALLE, M. F. 1999. The succession of vertebrates and plants across the Cretaceous-Tertiary Boundary in the Tremp Formation, Ager valley (SouthCentral Pyrenees, Spain). Geobios, 32(4), 617-627.

MARKEVITCH, V. S., BugDAEVA, E. V. \& BolotSKY, Y. L. 2000. Palynological evidence of vegetational change and dinosaur extinction in the Amur region. Paleontological Journal, 34(1), 50-53.

Mayr, C., Thümmler, B., Windmaier, G., AltenBACH, A. V., KÖler, H. \& TiEdemANN, R. 1999. New data about the Maastrichtian/Danian transition in the Southern Pyrenees (Ager Basin, Catalonia, Spain). Revista Española de Micropaleontologia, 31, 357-368.

MÉduS, J. 1986. Paléogéographie et systématique du genre Pseudoromeinipollenites au Crétacé supérieur. Actas de Palinología, 321-325.

Médus, J., Colombo, F. \& Durand, J. P. 1992. Pollen and spore assemblages of the uppermost Cretaceous continental formations of south-eastern France and north-eastern Spain. Cretaceous Research, 13, 119-132.

Médus, J., FeIST, M. ET AL. 1988. Prospects for recognition of the palynological Cretaceous/Tertiary boundary and an iridium anomaly in nonmarine facies of the eastern Spanish Pyrenees: a preliminary report. Newsletters in Stratigraphy, 18, 123-138.

Méon, H. 1990. Palynologic studies of CretaceousTertiary interval at El Kef outcrop, northwestern 
Tunisia: paleogeographic implications. Review of Palaeobotany and Palynology, 65, 85-94.

IÉON, H. 1991. Études sporopolliniques à la limite Crétacé-Tertiaire. La coupe du Kef (Tunisie Nord-Occidentale) étude systématique, stratigraphie, paléogéographie et évolution climatique. Palaeontographica B, 223, 107-168.

RoBADOR, A., SAMSÓ, J. M, SERRA-KIEL, J. \& Tosquella, J. 1990 Introduction in the Early Paleogene of the South Pyrenean Basin. IGCP Project 286. In: Field Trip Guidebook. ITGE. 159 pp.

SERRA-KIEL, J., HotTINGER, L. ET AL. 1998. Larger foraminiferal biostratigraphy of the Tethyan Paleocene and Eocene. Bulletin Société Géologique de France, 169, 281-299.

Stets, J., Ashraf, A.-R. et al. 1996. The Cretaceous-Tertiary boundary in the Nanxiong basin (continental facies, Southern China). In:
McLeod, N. \& Keller G. (eds) CretaceousTertiary Mass Extinctions. Biotic and Environmental Changes. Norton, pp. 349-371.

Sweet, A. R., Braman, D. R. \& Lerbekmo, J. F. 1999. Sequential palynological changes across the composite Cretaceous-Tertiary $(\mathrm{K}-\mathrm{T})$ boundary claystone and contiguous strata, western Canada and Montana, U.S.A. Canadian Journal of Earth Sciences, 36, 743-768.

Tschudy, R. H., PIllmore, C. L., ORth, C. J.; Gilmore, J. S. \& KNIGHT, J. D. 1984. Disruption of the terrestrial plant ecosystem at the Cretaceous-Tertiary boundary, Western Interior. Science, 225, 1030-1032.

VAJDA, V., RAINE, J. I. \& Hollis, C. J. 2001. Indication of global deforestation at the Cretaceous-Tertiary boundary by New Zealand Fern Spike. Science, 294, 1700-1702. 